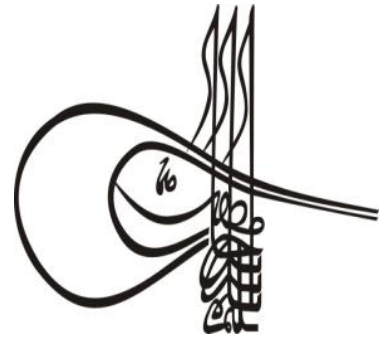

Received/Geliş: 01.01.2019
Turkigh Studies

\section{Language and Literature}

Volume 14 Issue 2, 2019, p. 441-456

DOI: 10.29228/TurkishStudies. 22585

ISSN: 2667-5641

Skopje/MACEDONIA-Ankara/TURKEY

Research Article / Araştırma Makalesi

Article Info/Makale Bilgisi

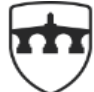

INTERNATIONAL BALKAN UNIVERSITY

EXCELLENCE FOR THE FUTURE IBU.EDU.MK

an Report Dates/Rapor Tarihleri: Referee 1 (27.01.2019)-Referee 2 (22.02.2019)

This article was checked by iThenticate.

\title{
MİNÖR EDEBİYATIN AKTÜEL BİR PANORAMASI
}

\author{
Fethi DEMIR* - Harun ARVAS ${ }^{* *}$
}

\begin{abstract}
öz
Minör edebiyat, genel anlamıyla azınlık olarak bulunan bir kitlenin majör dilde ürettiği edebiyat olarak tanımlanır. Tarih boyunca "minör bir söylem" edebiyat, sanat ve politika alanında hep var olmuştur. Varlığını kanonun dişında kuran bu söylem; küreselleşmenin, postmodernizmin, çokkültürlülüğün egemen olduğu bugünün dünyasında daha belirgin bir hâle gelmiştir. Modernizmin yaşadığı kriz, büyük ideolojik anlatılara olan güvenin sarsılması, mikro milliyetçilikler, azınlık araştırmaları, göçler, öteki kimliklerin kendini ifade edebileceği sosyal platformların çoğalması minör edebiyat söylemini görünür hâle getirmiştir. Sosyal medyanın, internet teknolojisinin ve görselliğin hâkim olduğu bu çağda her türlü marjinal edebiyat ve kültür unsuru görünürlük kazanmıștır. Son tahlilde, güncel hayatın edebiyat üretimlerini analiz etmek için Minör edebiyat kavramını göz önünde bulundurmakta fayda vardır. Çünkü çokkatmanlı, üstkurmacaya ve metinlerarasılığa dayanan karnavalesk bir atmosferde kotarılan bu edebiyat üretimlerinin tahlilinde, "minör bir söylemin" varlığını göz ardı etmek, eserin anlam dünyasının tam olarak anlaşılmasına engel olacaktır. Dilin güçlü bir yersizyurtsuzlaştırmaya uğratılması, her şeyin içkin bir politik değere ulanması ve aynı zamanda söylemin kolektif bir değer taşıması gibi minör edebiyatın temel kriterleri bağlamında konuyu derinleştirmek, hem Batı edebiyatlarında hem de Türk edebiyatındaki izdüşümlerini tartışmak, minör edebiyat kavramı üzerine yapılacak bundan sonraki araştırmalara ve tartışmalara önemli katkılar sunacaktır. Bu makalede amaçlanan da minör edebiyatın güncel tartışmalar çerçevesinde biçimlenen aktüel bir panoramasını sunmaya çalışmaktır.
\end{abstract}

Doç. Dr., Van Yüzüncü Yıl Üniversitesi, Eğitim Fakültesi, Türkçe ve Sosyal Bilgiler Eğitimi Bölümü, Yeni Türk Edebiyatı Anabilim Dalı, E-posta: mfethi_demir@yahoo.com 
Anahtar Kelimeler: Minör edebiyat, aktüel edebiyat akımları, kollektifleşme, dilin yersizyurtsuzlaşması.

\title{
AN ACTUAL PANORAMA OF THE MINOR LITERATURE
}

\begin{abstract}
Minor literature is defined as the literature of a minority in the majority's language. Throughout history, "a minor discourse" has always existed in literature, art and politics. This discourse that establishes its existence outside the canon has become more prominent in today's world which is dominated by globalization, postmodernism and multiculturalism. The crisis experienced by modernism, the shaking of trust in great ideological narratives, micro-nationalisms, minority research, immigrations, the proliferation of social platforms in which other identities can express themselves popularized Minor literature discourse. In today's world which is dominated by social media, internet technology and visuality, every kind of marginal literature and cultural item has somehow become visible. In the final analysis, it is now imperative to consider the concept of Minor literature to analyse the literary productions of our age. Because in the analysis of contemporary literary works, which are based on multidimensionality, metafiction and intertextuality and which are achieved in a carnivalesque atmosphere, ignoring the existence of a "minor discourse", will hinder a complete understanding of the meaning of the work. To deepen the subject in the context of the basic criteria of minor literature, such as a strong degradation of the language, the imposition of everything as an intrinsic political value and at the same time a collective value of discourse, discussing its projections in both Western and Turkish literature will significantly contribute to the future researches and discussions on the concept of Minor literature. The aim of this article is to present an actual panorama of Minor literature which is shaped within the framework of current debates.
\end{abstract}

\section{STRUCTURED ABSTRACT}

Minor literature is defined as the literature of a minority in the majority's language. Throughout history, "a minor discourse" has always existed in literature, art and politics. This discourse that establishes its existence outside the canon has become more prominent in today's world which is dominated by globalization, postmodernism and multiculturalism. The crisis experienced by modernism, the shaking of trust in great ideological narratives, micro-nationalisms, minority research, immigrations, the proliferation of social platforms in which other identities can express themselves popularized Minor literature discourse. In today's world which is dominated by social media, internet technology and visuality, every kind of marginal literature and cultural item has somehow become visible. In the final analysis, it is now imperative to consider the concept of Minor literature to analyse the literary productions of our age. Because in the analysis of contemporary

Turkish Studies - Language and Literature

Volume 14 Issue 2, 2019 
literary works, which are based on multidimensionality, metafiction and intertextuality and which are achieved in a carnivalesque atmosphere, ignoring the existence of a "minor discourse", will hinder a complete understanding of the meaning of the work. To deepen the subject in the context of the basic criteria of minor literature, such as a strong degradation of the language, the imposition of everything as an intrinsic political value and at the same time a collective value of discourse, discussing its projections in both Western and Turkish literature will significantly contribute to the future researches and discussions on the concept of Minor literature. The aim of this article is to present an actual panorama of Minor literature which is shaped within the framework of current debates.

The emergence of the concept of minor literature is mostly dates back to the establishment of modern nation-states. The governing models which became authoritarian and put pressure on the different ethnic, religious, sectarian, cultural and ideological identities especially in the beginning of the 20th century led to the emergence of a minor literary movement which is in official language but against official discourse. Minor literature we discuss today, owes its existence to the developments in the world during World War II especially in continental Europe. The conceptual framework of minor literature largely develops in the direction of the studies of Deleuze and Guattari on Kafka's works. Even today, the minor literary debates in almost every region of the world are largely maintained in the context of the findings of Deleuze and Guattari on the subject.

The crisis experienced by modernism, the shaking of trust in great ideological narratives, micro-nationalisms, minority research, immigrations, the proliferation of social platforms in which other identities can express themselves have popularized Minor literature discourse. Thus, in the age of globalization we live in today, the boundaries have disappeared; events such as communication, internet technology, virtual networks, transportation facilities, migrations, wars, tourism etc. have made the world a global platform. Therefore, a minor literature has become a literary field that is seen and produced consciously or unconsciously in almost every country in the world. Multilingualism, multiculturalism, religious and ethnic hybridity, reproduction of the major language revealed as a result of postcolonial atmosphere in favour of minorities necessitate the use of Minor literature to perceive the literary world of the age in which we live. In fact, it wouldn't be wrong to say that Minor literature is the key concept of perceiving the world of literature. Thus, Deleuze and Guattari are rightly asking; how many people in the world are speaking a language that is not their mother tongue under the rule of an Anglo-Saxon hegemony? How many people do not even know their mother tongue? Moreover, how efficiently people speak their mother tongue or how many people do not even know the majority's language they are forced to use? These questions can be increased. For instance, the manifestation of which cultural, ethnic, sociological and psychological situations is the literature produced by the immigrants living in another country for two or three generations? Is it the end of national literature? Will everyone now produce their own Minor literature under the umbrella of a comprehensive and general world literature? Or will each ethnic, cultural, 
religious group break away from the main stream and sail into their own internal literature in the era of micro-nationalisms? In this demonstration society where private life has been moved to the public sphere, instead of forcing the narrative opportunities in major languages; will the minorities do literature in their mother tongue without bowdlerizing? It seems that beginning with feminism that will not narrow down the field of minor literature, it will evolve to another dimension with the participation of new species such as ecology, underground literature, dystopia, marginal lives, homosexuality, subcultural movements, dystopia and e-literature. As a result, Kafka's metaphoric expression of "walking a tightrope with the baby stolen from the cradle" will rise on the shoulders of the feminist, environmentalist, underground or dystopian writers.

Keywords: Minor literature, actual literary movements, minorities, collectivising degrading of the language.

\section{GİRIŞ}

Modernizmin yaşadığ kriz ve büyük ideolojik anlatılara olan güvenin sarsılması 20. yüzyılda, başta Batı dünyası olmak üzere insanlığı kendi gerçekliğiyle radikal bir biçimde yüzleşmek zorunda bırakır. Çünkü aydınlanma düşüncesinin skolastik düşünceyi yıkıp aklın ve pozitif bilimlerin ışığında insan odaklı yeni bir dünya kurma projesi; dünya savaşları, toplama kampları, atom bombaları, ekolojik dengenin bozulması, ekonomik eşitsizliğin artması, felaketler, açlık ve sefalet manzaralarıyla örülü bir atmosfer üretmesi ile derinden sarsılır. Öyle ki 20. yüzyılın tüm bütünlükçü politik sistemleri; yani toplumu bütün yönleriyle algılayıp dönüştürme vaadi sunan ideolojileri, büyük bir itibar kaybına uğrar. Artık, insanlığın ortak kaygısına dönüşen her şeyin daha da kötü olacağı düşüncesi; bilimin, kültürün, sanatın ve edebiyatın başat sorunsallarından biri hâline gelir. İşte böylesi bir atmosferden doğan "minör politika"; yan yana duruşu ortaya koyan, kolektif paylaşım alanları yaratan ve bir çözüm önerisinden çok, yaşamın kendisinin savunulmasına dayanan bir tarzda gelişir. İdeolojilere, yüksek değerlere, hiyerarşiye ve merkez ilke nosyonuna tepkisel bir biçimde bilimin, sanatın, kültürün odağına yerleşir. $\mathrm{Bu}$ alanlardan biri de edebiyattır.

Minör edebiyat, insanlığın ilk edebi üretimlerine kadar götürülebilecek tarihî bir arka plana sahiptir. Bilinçli, programlı ve belirli, eskilerin tabiriyle "efradını camî ağyarını man̂̂" bir tarifi yapılmamış olsa da varlığını tarih boyunca edebiyat, sanat, kültür ve politika alanında gerek açık gerekse içkin bir biçimde sürdürmüştür. Çünkü toplumların tarihi aynı zamanda kültürel, sosyal, sınıfsal, etnik, dinî, mezhepsel, cinsel anlamda ötekileştirilenlerin, dışlananların da tarihidir. Resmi tarihte ya da edebiyat anlamında kanonun içerisinde kendisine yer bulamasa da alternatif bir sanat, edebiyat, kültür akımı tarih boyunca hep olagelmiştir. Örneğin tüm avangart edebiyat akımları, müesses nizamı rahatsız edecek içerik unsurlarına sahip eserler ve dolayısıyla ideolojik, dini ve kültürel kimlikleri nedeniyle kimi edebiyatçılar kanonun dışına itilmiştir. Marquis de Sade'dan Emily Bronte'ye, Charles Bukowski'den Nazım Hikmet'e, Samuel Beckett'tan Necip Fazıl'a, Albert Camus'dan Namık Kemal'e, Salman Rüşdi'den Aleksandr Soljenitsin'e kadar birçok edebiyatçı ya eserleri ya da muhalif tavırları nedeniyle çoğu zaman görmezden gelinmiş, eserleri yasaklanmış, kovuşturmalara, hapislere ve sürgünlere gönderilmiştir. $\mathrm{Bu}$ nedenle anakronik bir yanılgıya kapılmadan, yani minör edebiyatın modernizm sonrası bir olgu olduğunu unutmadan, bu söylemi içeren eserlerin tarihini, insanlığın ilk edebi ürünlerine kadar uzatabiliriz. Kuşkusuz bugün kullandığımız modern anlamda bir minör edebiyat kavramının doğuşu ise daha çok modern ulus devletlerin kurulmasından sonraya dayanır. Özellikle 20. yüzyılın başında otoriterleşen, farklı etnik, dini, mezhepsel ve kültürel kimlikler üzerinde baskı kuran yönetim modelleri, kendini resmi dilde ama resmi söyleme karşı kuran bir minör edebiyat akımının 
doğmasına neden olmuştur. Bugünkü manasıyla tartıştı̆̆ımız minör edebiyat, varlığını II. Dünya Savaş1 y1llarında başta Kıta Avrupası olmak üzere dünyada yaşanan gelişmelere borçludur.

Minör edebiyatın ortaya çıkmasında iki temel kriter etkili olmuştur. Bunlardan ilki Nazi Almanya'sında olduğu gibi despot yönetimlerin farklı uluslar, dinî, etnik ve kültürel gruplar üzerinde kurduğu ağır baskılara karşı; bu ötekileştirilen kimliklere sahip edebiyatçıların travmalı bir bilinçle ürettikleri rizomatik, örtülü ve içkin yazma refleksidir. Başka bir ifadeyle minör edebiyat, azınlıkların majör bir dilde yaptıkları edebiyattır. Bu edebiyatın oluşmasında azınlıkların güç ve iktidar tarafından kendi kültürlerinden, dillerinden koparılması ve çoğunluğun dilinde düşünmeye, konuşmaya, okumaya ve yazmaya zorlanması belirleyicidir. Dolayısıyla minör edebiyatta çoğunluğun dili, önce bir zorunluluk gereği alınır; imkânsızlıklar, suskunluklar ve kekelemeler biçiminde yeniden dönüştürülür. Bir bakıma minör edebiyat, bir tercihten çok, bir zorunluluğun sonucunda ortaya çıar ve bir dizi güçlügü ve aynı zamanda paradoksal bir biçimde bu zorlukların yarattığı içkin yaratıcılığı ve imgelemi de bünyesinde barındırır. Nitekim yapısöküme uğratılan majör dilin imkânları zorlanarak politik, göçebe, imgesel derinliği olan entelektüel bir edebiyat üretilir.

Minör edebiyatın doğuşunu sağlayan ikinci etken ise postmodernizmin başta edebiyat, sanat, kültür ve politika olmak üzere yaşamın hemen her alanına egemen olmasıdır. Çünkü küreselleşme, teknolojik gelişmeler, kültürlerarası ilişkilerin yoğunlaşması, internet teknolojisinin bilgiyi, sanatı, edebiyatı evrensel bir düzlemde anında dolaşıma sokması minör edebiyatın neşvünema bulacağı zeminin genişlemesine olanak sağlar. Turizm, seyahat, göçler, ulaşım imkânlarının kolaylaşması eklektik, melez, çoğulcu toplumlar oluşturur. Öte yandan postmodernizmle yerel kültürler, etnik ve mikro değerlerin öne çıkması da minör edebiyat söylemini daha da belirginleştirir. Artık, egemen dili kendi beklentileri doğrultusunda kullanan, jakoben ve dayatmacı bir tavrı olan modernist tahakkümcü söylemi daha rahat ve özgürce sorunsallaştıran bir minör edebiyat, yaygınlaşır.

\section{Minör Edebiyatın Kavramsal Çerçevesi}

Minör edebiyat, daha çok, "dilin alışılageldik yapılarını bozarak anlamı öteleyen, egemen söylemi aşındıran, despotik yapılara karşı söyleyecek sözü olan, farklılıklara ve çoğulluğa açık, başka bir toplumsal biraradalığın mümkün olduğunu savunan politik bir edebiyat olarak" (Erkol, 2010: 57) kabul edilir. Bir başka ifadeyle "yayılmışın içindeki sıkışmışın, baskılayanın altındaki baskılananın, sayısal istatistikleriyle toplumsal/siyasal istatistiklerinin ters denge oluşturduğu açık bir gerçek olan çoğunluğun kenara ittiği azınlığın meşrulaştırılmasının bir reddidir adeta.” (Kuyumcu, 2010: 69). Bu nedenle minör edebiyat1; sorunsala dönüșen bir süreç olarak değerlendirmek mümkündür. Zira minör edebiyat, dilin ve anlatımın imkânlarının sonuna kadar zorlanarak kotarıldığı sürekli bir itiraz etme biçimidir. Tıpkı merkezsiz, kökensiz bir yapı olan köksapın (rizomun) yerin altında gelişmesi gibi minör edebiyat da resmi edebiyatın yüzeyinde değil, yeraltında gelişip filizlenir. Bu filizlenme "azınlık edebiyatlarının iddialarını, her zaman acil, koşullu ve aşkın kişiye meydan okumak biçiminde canlandırmaya yardımcı olacak bir söylemi somutlaştırır." (Gale, 2016: 302). Claire Barber-Stetson'a göre ise minör edebiyat, "birçok edebi hareketi tasvir etmek için kullanılan geçici sınırlar tarafindan daha az sınırlandırılmış ve bir metnin estetik ve şiirsel özelliklerine daha fazla odaklanan bir kategoridir." (Barber Stetson, 2014: 147). Öte yandan bir üslup ve tavır meselesi olan minör edebiyat için yazarın minör kimliğe sahip olup olmaması da tali bir durumdur. Çünkü yazarın yapıtlarında, "o dilin göçebesi-göçmeni olma hâli belirginse, söylemleri alışlageldik kalıplara ve sosyal, politik veya kültürel güç odaklarına tavır alıyorsa ve bu tavır metinlerde kolektif bir politik tavır biçiminde yer etmişse, o yazar minör edebiyatın alanındadır." (Erkol, 2010: 58). Ayrıca yazarın etnik kimliği nedeniyle yaşadığı toplumun "azınlığı" olup olmadığı konusu birincil bir önem taşımaz; etnik aidiyeti çoğunluğa mensup olan bir yazar da majör dili minör bir üslûpla kullanabilir, minör bir edebiyatçı olarak kabul edilebilir. 
Minör edebiyatın kavramsal çerçevesi, büyük oranda Deleuze ve Guattari'nin Kafka'nın eserleri üzerine yaptıkları incelemeler doğrultusunda gelişir. Bugün, dünyanın hemen her bölgesinde sürdürülen Minör edebiyat tartışmaları büyük ölçüde Deleuze ve Guattari'nin konu hakkındaki tespitleri bağlamında sürdürülür. Elbette özellikle 2000'li yıllardan sonra minör edebiyat kavramının bağlamı oldukça genişlemesine, Goethe'nin 19. yüzyılın başında dile getirdiği "Weltliteratur" (Dünya edebiyatı) kavramının büyük ölçüde gerçekleşmesine, postkolanyal edebiyatın klasik anlamdaki sömürensömürülen diyalektiğini başka bir boyuta taşımasına, e-edebiyat gibi postmodern çağın yeni minör odaklarının filizlenmesine rağmen Deleuze ve Guattari'nin Minör edebiyat hakkındaki fikirleri hâlâ belirleyiciliğini ve önemini korumaktadır. Deleuze ve Guattari, Antik Yunan'dan başlayarak Batı düşünce tarihinde majör-minör söylemlerinin oluşmasını ve bu gerilimli ilişkinin tarihi boyunca "majörleşmeye karşı duranı, duracak olanı keşfetmeye çalışır." (Özçınar, 2017: 75). Neticede Deleuze ve Guattari’nin Minör edebiyat kavramı hakkında ulaştıkları tanım şudur:

"Minör edebiyat, minör bir dilin edebiyatı değil, daha ziyade, bir azınlığın majör bir dilde yaptığ 1 edebiyattır. Ama temel özelliği, dilin güçlü yersizyurtsuzlaşma katsayısından her koşulda etkilenmiş olmasıdır." (Deleuze ve Guattari, 2015: 45).

Deleuze, Minör edebiyat üzerine bir yazısında "minöritenin birbiriyle ilişkili ama birbirinden bütünüyle farklı iki anlamı" (Murray, 1997: 255) olduğunu söyler. Burada birinci anlamıyla azınlık, sayılarının ne kadar olduğundan bağımsız bir şekilde çoğunluğun dışında bırakılmış ve dişarıda bırakılmadığında bile çoğunluğa çoğunluk olma hakkını veren, ölçüt, esas ve yasalarla ilişkileri bağlamında bir alt fraksiyon olarak tarif edilen bir azınlık kastedilmektedir. İkinci anlamı ise egemen söylem, azınlığın karşısına bir oluş hâli olarak minör azınlığı çıkarır. Burada minör/azınlık-oluş aslında bir hedeftir, bütün dünyayı ilgilendiren ve içine alan bir hedeftir; despotik ölçütlerin karşısına herkesin kendi yarattığı çeşitliliklerle ya da Deleuze'nin deyimiyle "kekelemelerle" çıkmasına denk düşer.

Minör edebiyat, bir nevi majör edebiyatın içindeki ötekidir, ötekilerin yaptığı edebiyattır. Kuşkusuz edebiyat anlamında ötekinin ortaya çıkışı; ulusal dillerin oluşması ve beraberinde gelişen sömürgecilik faaliyetlerine kadar uzanan bir tarihî arka plana sahiptir. Kıta Avrupa'sında güçlenen ulus devletlerin girdiği sömürgecilik yarışı ve bu sömürgecilik yarışının kültürel ve sosyal boyutunu oluşturan ulusal dillerin, kimliklerin ve kültürlerin farklı uluslara ve ülkelere dayatılması zaten "edebiyatta minör bir söylemin" neşvünema bulduğu atmosferdir. Kültür emperyalizmine karşı çıkmak isteyen, sömürgeleştirilen ülkelerin edebiyatçıları, çoğu zaman sömürgeci dili kullanarak, bir nevi sömürgeci dilin imkânlarını ona karşı bir eleştiri ya da başkaldırı aracına dönüştürerek edebiyat eseri üretirler. Elbette bu süreç, belirli bir birikimin dahası sanc1lı bir mücadelenin sonucudur. Uzun y1llar kültür emperyalizmine maruz kalan sömürgeleştirilen ülke edebiyatçıları, önce sömürgeci dilde yazmaya alıştırılır, bir müddet sonra içine düştükleri kimlik krizini bir biçimde aşarak sömürgeci dilde, sömürgeciliğe karşı, eleştirel ve muhalif bir söylem kurarlar. Fakat bu aşamaya varmak bir dizi kompleks ve travmatik sorunla cebelleşmeyi gerektirir. Nitekim birçok ülkede yüzyıllar boyunca süren ve hâlâ değişik biçimlerde devam eden bu olgu, geride birçok sosyal, kültürel ve toplumsal komplikasyon bırakmış, halihazırda bırakmaya da devam etmektedir. "Özellikle İngilizce, Fransızca ve İspanyolcanın kolanyal diller olarak dünyanın birçok ülkesinde ana dili eğitim dışı bırakıp, gündelik yaşama indirgediği gerçeği” (Pazarkaya, 2018: 126) bu ülkelerde üretilen edebi ürünlere bakıldığında çok açık bir biçimde gözlemlenebilir. Paradoksal bir biçimde çift dilli edebiyatçılar üreten bu atmosfer, edebî yaratıcılığı çoğu zaman geliştirir. Çünkü sömürgeci dilde yazmak, yazarı/şairi ana dilinin etkisinden kurtarmaz. Ana dilinin geleneği, kültürel ve tarihsel belleği, sömürgeci dilde yazma sürecine bilinç veya bilinçdışı boyutunda etki eder ve ortaya farklı, özgün, protest ve alegorik bir edebiyat çıkar. Bu bağlamda minör edebiyat özü itibariyle "bazı edebiyatları değil, büyük (ya da yerleşik) diye adlandırılan edebiyatın bağrındaki her türlü edebiyatın devrimci koşullarını niteleyen." (Bayrak, 2016: 347) bir edebiyattır. Bir nevi minör edebiyat "yerleşik ve baskın/baskıcı perspektife meydan okuyan büyük nehrin içindeki ters akıntıdır. Akıntının yönünü değiştirmek istemeyen -çünkü bu onu ana akım 
yapacaktır- ama varlığıyla o büyük akışın önüne boyuna bakmadan dikilip neticede göz kamaştırıcı bir anafor yaratan yıkıcı, "tekinsiz" bir ters akıntıdır." (Güçbilmez, 2003: 4).

Minör edebiyat, isminin içerdiği anlamın tersine "majör" bir duruma tekabül eden önemli bir konudur. İmparatorluklar sonrası kurulan ulus devletlerin çoğu zaman farklı etnik, mezhepsel ve kültürel grupları baskılaması, asimile etmeye çalışması bugün bile tüm boyutlarıyla açıklan(a)mamış; edebi olduğu kadar politik, psikanalitik, sosyolojik, kültürel ve filolojik anlamda irdelenmesi gereken bir olgudur. Nitekim Deleuze ve Guattari de minör edebiyatı bir sorunsal olarak değerlendirip küçük bir edebiyat olmadığını dile getirirler (Deleuze ve Guattari, 2015: 45) Minör, majörün içindeki büyük edebiyattır aslında. Minör edebiyat, orijinal olan her şeyin vuku bulduğu, eklektik, çokkatmanlı bir noktadır. İmparatorlukların yıkılmasıyla yerlerinden, yurtlarından edilen ve kendi dillerinden koparılan toplulukların majör dilde konuşmaya başlaması ve hâkim, egemen olan dilin kisvesi altında kendi dillerinde mırıldanmaları minör edebiyatın çıkış noktasıdır. Üzerine çok fazla durulmayan/durulamayan minör edebiyat, küresel kapitalizm çağında yaygınlaşır. Zira göçler, modernleşme, postmodernizm gibi gelişmeler; eklektik, çokkültürlü karmaşık toplumsal yapılar oluşturur. Minör edebiyat da gücünü bu renkli, eklektik, karnavalesk atmosferde daha fazla görünür hale gelen azınlıkların, etnik ve kültürel grupların majör dildeki edebi üretimlerinden alır.

Minör edebiyatın bir diğer özelliği ise üreticisinin; bilincindeki bölünmüşlükten yaratıcı bir metin çıkarmasında gizlidir. Nitekim yazar/şair açısından bakıldığında ise asıl zor olan; majör edebiyat içerisinde dili yurdu ve evi gibi görmemesi, kendisini evinde gibi hissetmemesi, bir bakıma kendi evine yabancılaşmasıdır. Tüm bu yabancılaşma ve kimlik krizi içerinde yine de yılgınlığa düşmemesi ve majör dilin anlatım imkânlarını sonuna kadar zorlayarak edebiyat üretmesidir. Bu da minör söylemin gücünü ifade eder. Çünkü minör edebiyatta kanonik dilin yerleşik bütün kuralları adeta altüst edilir. Dil çölleştirildiği gibi aynı zamanda yersizyurtsuzlaştırılır. Bir bakıma "minör edebiyatın yazarı majör edebiyatın içerisindeki azınlığın bir kurtarıcısı ve elçisi konumundadır. $O$, temsil ettiği azınlığın sesinin, çığlığının dışavurumudur." (Batu, Kaygalak, www.youtube.com: 12.06.2018).

Deleuze ve Guattari Kafka üzerine yaptıkları incelemede minör edebiyatın üç temel özelliğinden bahsederler. Bunlardan ilki dilin ana temel özelliği güçlü "yersizyurtsuzlaşma" katsayısından her koşulda etkilenmiş olmasıdır (Deleuze ve Guattari, 2015: 46). Deleuze ve Guattari, majör dilde yapılan bu azınlık edebiyatı için Kafka'yı örnek verirler. Kafka, Prag Yahudilerine yazı yolunu kapatan ve edebiyatlarını olanaksız kılan çıkmazı "yazmama olanaksızlığı", "Almanca yazma olanaksızlığı", "başka türlü yazma olanaksızlığı" şeklinde tanımlamaktadır. Yazmamak olanaksız bir şeydir. Çünkü ulusal bilinç ister belirsiz olsun ister baskı altında olsun zorunlu olarak bir edebiyattan geçer. Almancadan başka dilde yazma olanaksızlı̆̆ ise Prag Yahudileri için başlangıçtaki Çek yerliyurtluluğu ile ortadan kaldırılamaz bir uzaklık duygusu anlamına gelmektedir. Almanca yazma olanaksızlığı ise kitabi ya da yapay bir dil konuşan baskıcı azınlığın, bizatihi Alman nüfusunun yersizyurtsuzlaştırılmasıdır. Yahudiler olsa olsa hem bu azınlığın bir parçasıdırlar hem de tıpkı "Alman çocuğunu beşiğinden çalmış olan çingeneler" gibi bu azınlıktan ötelenmişlerdir. Sonuçta Prag Almancası minör kullanımlara uygun, yersizyurtsuzlaşmış bir yazın dilidir. Öte yandan Gilles Deleuze ve Claire Parnet, Kafka ile Backett'in eserlerinden hareketle kaleme aldıkları Diyaloglar adlı kitaplarında "tek dilde bile iki dilli olmak" ve majör dilde "bir azınlık dili yaratmak" gibi saptamalar yaparak minör edebiyatın öncelikle bir dil ve üslûp meselesi olduğuna dikkat çekerler (Deleuze, Parnet, 1990: 19).

Minör edebiyat, egemen ve genel geçerliliği olan kurallarla örülmüş majör dilin sınırları içerisinde sıkışıp kalmaz, aksine kendi söylemini sonuna kadar uç noktalara taşımayı savunur. $\mathrm{Bu}$ durumu bir nevi "sınır edebiyatı adlı geniş bir oluşumun ifadesi olarak görür." (Gilmore, 2015: 54). Kanonik edebiyatın duvarlarını yıkan minör söylem, toplumsal düzen ve onun despotik baskıları karşısında engellendiği, ötekileştirildiği ve dışlandığı hayattan adeta bir kaçış çizgisidir. Nitekim 
Deleuze ve Guattari Minör edebiyat için metaforik bir biçimde "sı̆ğnacak bir yer arayan bir köpek, yuva yapan bir fare gibi yazmak" tespitini yaparlar. Bu bağlamda minörlük hâli kendi az gelişmişlik noktasını, kendi taşra ağzını, kendi üçüncü dünyasını, kendi çölünü bulmaktır. Kendi ana dilini bir yabancı gibi konuşmak, içinde edebiyat yapılan majör dili, başka bir ifadeyle kanonun dilini minörleştirmektir. Özcesi minör edebiyat var olan deneyimleri sarsabilmeli, bununla birlikte yeni seslere bir oluş gücü sunabilmelidir. Dilin en uç noktalarında dolaşıp onun sınırlarını genişleterek yerleşik dilin kalıplarını, despotizmini yıkmalıdır. Çünkü minör söylem dilbilgisel kuralların egemen olduğu dünyanın diliyle hesaplaşan cesur bir duruştur. Ancak "majör dilin içinden delikler açarak ve kendine özgü bir azınlık dili yaratarak tek dilde iki dilli olabilmeyi başarmış, ayrıca anlatımda mutlak ve tek bir pozisyona dayanarak, sürekli akış hâlinde bir pozisyonlar/merkezler çokluğunu ortaya koyarak" (Demirtaş, 2015: 15) bu devrimci duruşunu sağlayabilir.

Minör edebiyattaki dilin devrimci kullanımı, bu özelliğini yazarın iki dil arasında kalmışlığının yarattığı yaratıcı ve özgün imgelem dünyasından alır. Zira yazar, iki dilin, geleneğin ve kültürün varlıklarını yaratıcı müdahalelerle sentezler. Başka bir ifadeyle yazar, eserlerinde uçurumun kıyılarında, imkânsızlıkların ve hatta ölümün sınırlarında dolaşır. Onun bu hâli, metinlerinde cümleleri sürekli kırmasına, kesik kesik alt alta yazmasına, cümleleri yan yana fakat farklı kombinasyonlarla birleştirmesine ve böylece zengin anlam çağrışımlarına ulaşmasına imkân verir. Zaten minör edebiyatın dili de "inşa edilen değil, inşa edilene karşı direnen tam da o kıyıdan somutlaşmış, bedenselleşmiş bu dile inat başka bir dili çağırmaya meyillidir." (Şahin, 2017: 44).

Minör dil; majör dili ve onun tabanını kırarak söylemi yoğunlaştırır. Majör dili gitgide bilerek bilinçli anlamından uzaklaştırmaya çalışır. Dilin altını üstüne getirerek, sözdizimi sınırlarını zorlayarak ve dilde uçurumlar yaratarak dili oyup onda sonu görünmeyen karanlık delikler açar. Böylece minör bir kullanımı gerçekleştirir. Bir bakıma minör dili "aslında majör dil içerisinde dili kekeletmek, tekrarlatmak ya saçmalatmak, dil içinde bir tür yabancı dil icat etmektir." (Şahin, 2015: 14). Denilebilir ki minörden daha büyügü, daha yaratıcısı ve daha devrimcisi yoktur. Devrimci ve yaratıcılık egemen dile karşı dilbilimsel ve sözdizimsel bir dilbilgisi, bir yeni anlatım tarzı çağrısı olarak anlaşılmalıdır. $\mathrm{O}$ halde minör edebiyat, azınlık ve çoğunluk dillerini yersizyurtsuzlaştırır; farklı bir anlatım tarzını, bununla beraber bir anti söylem duruşunu yeğler. Böylelikle en majör dilde dünyaya gelenler bile kendi dillerinde bir yabancıymış gibi yazarlar ve majör dili klasik sentaks, yapı ve anlam dünyasının dışına iterek bir bakıma çöle sürerler. Neticede minör edebiyat "yazılmış olduğu doğal dili yapısöküme uğratır ya da parçalara ayırır, başka bir ifadeyle sentetik yaratım yoluyla yeni bir dil oluşturur. Dil, onu yöneten sistemin ötesine geçer, onu ortalama dilin etimolojik skalasının dışına iter. Bu da dilin sessizleşmesini değil, her zamanki ifade sınırlarından uzaklaşmasını sağlar." (Fletcher, 2011: 54).

Minör yazarlar, dili majör kültüre mensup yazarlardan farklı işler. Nitekim "büyük yazarlar için dil, dilbilimsel işaretleri, onlardan önce gelen gibi görünen anlamlarla güvenilir bir şekilde eşleştirir; bu da hazır bulunan bir gösterge sağlar. Tersine Minör edebiyatın yazarları, kültür merkezlerinden siyasi ve çoğunlukla coğrafi nedenlerden uzaktırlar; bu durum, ikinci bir dil kullanmalarıyla karmaşık hâle gelebilir." (Adar, 2016: 23). Ayrıca dillere, standart olmayan kullanım ve anlamlı veya kapsamlı bir temsil oluşturmak için güvenilmez dilsel araç kiti ile karakterize edilen konumdan yaklaşırlar. Deleuze ve Guattari bu durumu "metodileştirme" olarak adlandırır. Dil; doğru yerini, jargonunu ve ifadesini kaybeder ve minör edebiyat yazarını, kendi diline göre konumunu düşünmeye zorlar.

Minör edebiyatın ikinci özelliği, her şeyin politik bir değer taşımasıdır. Majör dilde yapılan edebiyatlarda çoğu zaman bireysel konular, toplumsal ve politik bir arka plana bağlanmaz. Minör edebiyat ise tümüyle farklıdır. "Onun daracık mekânı, her bireysel sorunun doğrudan siyasete bağlanmasını sağlar. Yani bireysel sorun, içinde bambaşka bir öykü hareket ettiği oranda zorunlu, vazgeçilmez ve mikroskop altında büyütülmüş hâle gelir." (Deleuze ve Guattari, 2015: 46). Buradaki durum, yeni bir söyleme, yeni bir dünyaya açılan kapıdır. Yani azınlığın; bireysel, toplumsal ve politik 
alanlara bulaşmasıdır. Çünkü minör edebiyat yazarının varoluşsal travması, ne kadar bireysel durumlardan kaynaklanırsa kaynaklansın her zaman toplumsal, kültürel, etnik, ideolojik ya da dinî birtakım referanslara bağlanır. Bu nedenle minör edebiyattaki her söylem, her tema ya da üsluba dair her deneysel girişim bir biçimde politik anlamda "minörlük durumuna" gönderme yapar. Neticede "minörlük (...) birinci anlamıyla azınlık, sayılarının ne kadar olduğundan bağımsız olarak çoğunluğun dışında bırakılmış ya da dışarıda bırakılmadığında bile çoğunluğa çoğunluk olma hakkını veren, ölçüt ve yasalarla ilişkileri içinde bir alt fonksiyon olarak tarif edilen bir grubun içinde bulunduğu durumdur." (Güçbilmez, 2003: 7).

Minör edebiyat aslında Oedipusçu bir fantasma değil, siyasal bir programdır. (Deleuze ve Guattari, 2015: 46). Hatta "açıkça ve radikal bir biçimde politiktir; en konuşulmamış olanı, konuşulmadıkça acılaşıp bodrum katında her an yangın çıkarabilecek bir birikime dönüşebilecek yabancı düşmanlığını çoğunluğun kalbine doğru yürüyen bir iğne olarak görür.” (Güçbilmez, 2017: 39). Fakat minör edebiyatın bu politik olma durumu, minör olanla azınlık olanın aynı şey olduğu yanılsamasını doğurmamalıdır. Elbette minör edebiyat, içkin anlamda politik bir karakter taşır; ama bu içkin politik söylem azınlığın jargona ve basmakalıp ifadelere dayanan üslûbunun çok ötesindedir. Çoğu zaman majör dili ustaca kullanan, hatta onu majör kültürde yetişmiş yazarlardan daha iyi işleyen minör yazarlar vardır. Bu bağlamda minör edebiyat, aynı zamanda küçük ya da öteki değil, aklın ve algının sınırlarını zorlayan yeniliktir. (Özçınar, 2017: 76). Neticede politik işlevini de açıkça ve doğrudan muhalefet etmek yerine onun içine sızarak gerçekleştirmeye çalışır.

"Minör olmak, majör bir dili almak ve onu, tercih ettiğimiz kimliği ifade edebilecek şekilde konuşturmaktır. Minörün bu siyasal boyutu kritiktir; sanatta, edebiyatta ve dilde minör pratikler için toplumun majör sesinin normal alışkanlıklarını istikrarsızlaştırma imkânına sahiptir. Bu nedenle minör bir şekilde davranmak hâkim bir siyasal sisteme muhalefet etmek değil, o sistemin içinde yer almak ve onu içeriden değiştirmek demektir." (Sutton ve Jones, 2016: 73).

Minör bir edebiyatın politik söylemi, marjinalize edilmiş duyulara ve hislere olan bir arzuyu teşvik ederek geleneksel edebi hiyerarşileri değiştirme potansiyeline dayanır. Bu nedenle minör bir şekilde davranmak hâkim olan bir siyasal sisteme muhalefet etmek ve o sistemin içinde yer almak ve onu içeriden değiştirerek alt üst etmektir. Bu bağlamda minör söylem yenilikçi, radikal ve devrimci bir söylemdir. Çünkü "Minör dediğimizde aslında aklımıza küçük ya da öteki değil, aklın ve olgunun sınırlarını zorlayan bir yeni gelir." (Özçınar, 2017: 76).

Minör edebiyatın üçüncü bir özelliği ise "her şeyin kolektif bir değer taşımasıdır". Zira "minör edebiyatta yetenekli kişilere bolca rastlanılmadığından koşullar, şu ya da bu 'usta' ya ait olan ve kolektif sözcelemden kaynaklanmaz. Bu yüzden yetenekli kişilere az rastlanması aslında bir bakımdan yararlıdır. Yazarın tek başına dile getirdiği şey zaten ortak bir eylemi oluşturur. Bunun için söylediği ve yaptığı şey, başkaları hemfikir olmasa da zorunlu olarak siyasaldır. Siyasal alan her türlü söyleme bulaşmıştır." (Deleuze ve Guattari, 2015: 48-49). Bundan kasit, sözcelemin kolektif olarak düzenlenmesinin gerekliliğidir. Nitekim Minör edebiyat yazarı, sadece kendi duygularını dile getirmez, aynı zamanda mensubu olduğu "minör toplumunun" sözcülüğünü de yapar. Böylece üretilen edebiyat, yazarın bireyselliğini aşar, siyasal olana bağlanır ve kolektif bir karakter kazanır.

"Özne yoktur, yalnızca kolektif sözcelem düzenlemeleri vardır -ve edebiyat, bu düzenlemeleri, henüz dışarıda verili olmadıkları ve yalnızca gelecekteki şeytani güçler ya da oluşturulacak devrimci güçler olarak var oldukları koşullarda dile getirir. Kafka'nın münzeviliği onu, bugün tarihin içine işlemiş olan her şeye açmıştır. K harfi, artık ne bir anlatıcıyı ne de bir kişiyi gösterir; bir bireyin, münzeviliği için kendilerine bağlı olması ölçüsünde, makinesel olan bir düzenlemeyi ve kolektif bir faili gösterir. (Bireyin kolektif olandan ayrılabilmesi ve kendi işini yürütebilmesi, yalnızca bir özneyle ilişkilidir)" (Deleuze ve Guattari, 2015: 48-49). 
Minör edebiyat denince akla gelen ilk yazar Kafka'dır. (Deleuze ve Guattari, 2015: 23). Kafka; Almanca, Çekçe ve Yiddiş dillerini içi içe koyacak şekilde kullanan çok dilli bir yazardır. Dilleri düşünsel ve üslûpsal açıdan sentezler, hatta tiyatro metinlerindeki gibi rolleri dahi birbirleriyle karıştırır. Franz Kafka, eserlerinde Prag Yahudilerinin yazıya ulaşmalarını engelleyen karanlık ve derin çıkmazlardan kurtulmayı hedefler. Majör dilin karşısına minör dili çıkararak imkânsız olanı başarır. Kafka kendisine farklı bir dünya ve gerçeklik imgesi yaratarak dili alışagelmiş yollardan saptırır ve farklı bir dil oluşturur. Deleuze'ün tabiriyle adeta bir şizofren-yazar tarzıyla hareket eder. Metni parçalar, bozar ve genel geçer kuralların baskıcı despotizmine karşı durur; bir şizofren-yazar gibi "yazarken kadın olur, hayvan ya da bitki olur, algılanamaz olana dek molekül olur." (Deleuze, 2007: 9) Esasında "Kafka'nın ihtiyacı olan şey, kendini ifade edebileceği, şekillendirip yeniden yaratabileceği bir ifade yoludur. Buna sahip olabilmesi, kendisini ifade edebilmesi, tamamen farklı hissettiği bu yaşam içerisinde kendisine bir yer edinerek varlığını onaylayabilmesinin bir sembolüdür belki de." (Tuncay, 2012: 76).

Minör edebiyat bağlamında adı geçen bir diğer yazar ise Samuel Beckett'tır. Nitekim Deleuze ve Guattari, minör bir yazarın başlıca örneği olarak İngiliz egemenliğinde doğmuş İrlandalı yazar Samuel Beckett'ten bahsederler. Beckett'in Fransizca, Molloy'de yayınlanan ilk romanı üzerine odaklanarak Backett'in minör bir yazar kabul edilmesi gerektiğini savunurlar. Yine James Joyce, Salman Rüşdi, gibi yazarlar minör edebiyat bağlamında öne çıkan kişilerdir. Yine postkolonyal bir dönemde yazan Ngugi wa Thiong'o, Chinua Achebe, Wole Soyinka, Nadime Gordimer, Nureddin Farah, J.M. Coetzee, Abdulrezak Gurnah gibi Afrikalı yazarları anmak gerekir. Özellikle sömürgeleştirilirmiş Afrika ülkelerinde doğan bu yazarlar, kolonyal bir eğitim sürecinden geçmelerine rağmen, "sömürgeci ülke ve kültürüne karşı çok keskin olmasa farklı düşüncelerle farklı tutumlar geliştirirler." (Taş, 2018: 23).

Minör edebiyat; okura yeni yorumlama imkânları, estetik haz ve entelektüel derinlik sunan bir edebiyattır. Başka bir ifadeyle okuru düşünsel, felsefi ve dilsel anlamda zorlar; fakat neticede ona tanıdık bir çevre üzerinde farklı bakış açısı ve perspektif sağlar. Böylece okur, alışılmadık uyaranlara duyarlı olur ve eserdeki bağlantıları çözerek yeni ve olağandışı zevkler alabilir. Elbette okurun da minör bir eserin içeriğine ve üslûbuna vakıf olabilmesi için belirli bir altyapısının olması, en azından minör edebiyatın temel özelliklerini bilmesi gerekir. Zaten Deleuze ve Guattari, minör edebiyat kavramını öne sürerek tüm dünyada pek çok yeni araştırma alanları açan bir konseptle modern okuyucuya eski tür, tip, biçem ve ifade tarzları dışında farklı bir okuma biçimi önerirler. Bir bakıma Kafka'nın eserlerini minör edebiyat bağlamında irdelemek, o güne değin Kafka'yı farklı akımların, edebi yaklaşımların, felsefi ve estetik kuramların skalasında okumaya alışmış okura, ilk başta yadırgatıcı gelir. Çünkü Kafka' yı alegori, sembolizm, teoloji gibi klasik şerh metotlarının ötesinde analiz etmek için köklü bir dönüşüm yaşamak gerekir. "Nitekim Kafka'nın eserleri 'çok dilli' yazı pratikleri için bir toplanma noktası ya da modeli oluşturacak niteliktedir.” (Bensmaia, Deleuze ve Guattari, 2017: 8). Neticede sadece Kafka'nın eserleri değil; minör edebiyat bağlamında değerlendirilen eserlerin birçoğu popüler olmamış, herkesin kolay anlamayacağı ya da popüler olup okunmuşsa bile esas iletisi tam anlamıyla kavranamamış türden anlatılardır. Örneğin Samuel Beckett'ın absürt oyunları ya da James Joyce'un modernist romanları anlaşılması zor, felsefi ve entelektüel boyutu güçlü, soyutlamalar ve alt göndermeler içeren metinlerdir.

Minör edebiyatın, her ne kadar "efradını camî, ağyarını man̂̂" bir kavramsal çerçevesi henüz oluşturulmamış olsa da önümüzdeki dönemlerde etkinliğinin artacağı aşikârdır. Küresel çağın, çokdilli melez toplumların ve postmodern atmosferin neticesinde yaşamın her alanında olduğu gibi edebiyat sahasında da bir eserin anlaşılması, anlam katmanlarının çözümlenmesi, örtük iletilerinin ifşa edilmesi minör edebiyat kuramının bilinmesini zorunlu kılmaktadır. Bu bağlamda kavram, ölçüt, tarihçe, yazar, eser ve okur kriterlerinden hareketle minör edebiyatın genel özelliklerini şöyle sıralayabiliriz: 
a) Minör edebiyat, azınlığın çoğunluğun dilinde yaptığı bir edebiyattır.

b) Minör edebiyat, edebiyat tarihi boyunca varlığını içkin bir biçimde de olsa hep sürdürmüştür.

c) Modern anlamda minör edebiyatın doğuşu sömürgecilik faaliyetleriyle ve ulus devletlerin ortaya çıkmasıyla ilişkilidir.

d) Avrupa'daki faşizan ve totaliter yönetimler minör edebiyatın gelişmesinde etkili olmuştur.

e) Küreselleşme, teknolojik gelişmeler, göçler, postkolonyalizm ve postmodernizm minör edebiyatın hem oluşumuna hem de görünürlüğüne doğrudan etki etmiştir.

f) Soğuk Savaş döneminin bitmesi ve Sovyet Bloğunun çöküşü, özellikle üçüncü dünya ülkelerinde minör edebiyatı yeni bir muhalif ve politik mahfil hâline getirmiştir.

g) Minör edebiyat, majör dilin sınırları içerisinde sıkışıp kalmaz, aksine kendi söylemini sonuna kadar uç noktalara taşır.

h) Minör edebiyatın temel özelliği dilin yersizyurtsuzlaşmasından her koşulda etkilenmiş olmasidır.

i) Minör edebiyat yazılmış olduğu dili yapısöküme uğratarak parçalara ayırır, başka bir ifadeyle sentetik yaratım yoluyla yeni bir dil yaratır.

j) Minör edebiyatta her şey kolektif bir değer taşır.

k) Minör edebiyatın yazarı çokdilli veya çokkültürlüdür.

1) Minör edebiyat örtük ve içkin bir ileti taşır.

m) Minör edebiyat yerleşik ve baskın/baskıcı perspektiflere meydan okur. Büyük bir nehrin içinde ters akıntı özelliği gösterir.

n) Minör edebiyat temsili değil, yaratıcılığı esas alan bir edebiyattır.

o) Minör edebiyat içerik ve üslûp özellikleri bakımından devrimci bir karaktere sahiptir.

\section{Türkiye'de Minör Edebiyat}

Türkiye, imparatorluk bakiyesi bir ülke olması, jeopolitik konumu ve zengin kültürel hinterlandı sebebiyle minör edebiyat bakımından oldukça verimli bir ülkedir. Renkli, zengin ve kadim bir edebi mirasa sahip olmasına rağmen; bu zenginliğini yeterince ortaya çıkardığını söylemek güçtür. Nitekim yaklaşık iki asırlık bir modernleşme çabası içerisindeki Türkiye'de minör edebiyat sahasında yapılan çalışmalar yok denecek kadar azdır. Türkiye'nin tarihî, sosyal, kültürel, sanatsal ve edebi atmosferi anlamında oldukça önemli veriler içeren böylesi bir alanda yapılacak bilimsel çalışmaların olumlu katkılar sunacağı söylenebilir. Çünkü özellikle Osmanlı'yı oluşturan uluslarda güçlenen milliyetçilik vurgusu (Ermeni, Rum, Arap vb.), 19. yüzyıldan itibaren Türk edebiyatında da minör bir söylemin filizlenmesini tetikler. Nitekim bu eğilimden etkilenen bazı edebiyatçılar, kendi etnik veya dinî aidiyetlerine vurgu yapan eserler kaleme alır. Öyle ki bu eğilimlerinden dolayı eserleri yasaklanan, sansürlenen ya da en hafif tabiriyle yadırganan epey edebiyatçı vardır. Özellikle imparatorluktan ulus devlete geçiş aşamasında Türkçe yazılmasına rağmen Türk edebiyatına dâhil edilmeyen kimi eserlere, kendi ana dilinde yazma imkânı bulamadığı için Türkçeye yönelen edebiyatçılara rastlamak mümkündür.

Öncelikle Türkçe olmalarına rağmen Ermeni ve Grek alfabesiyle yazılmış kimi eserler, Türk edebiyatı içerisine dâhil edilmez. Etnik ve dini anlamda azınlıkların ürettikleri Türkçe edebiyat, ülkenin politik ve toplumsal koşulları nedeniyle görmezden gelinir. Üzerinden yaklaşık iki asırlık bir süre geçmesine rağmen bugün bile, benzer saiklerle bu eserler, Türk edebiyatı içerisinde değerlendirmez. Oysa bu eserler dil ve içerik olarak incelendiğinde o dönemki diğer edebi metinlerle büyük benzerlikler gösterir. Örneğin Vartan Paşa'nın Ermeni harfleriyle yayımlanmış olan Akabi Hikâyesi, dönemin genel toplumsal atmosferini Ermeni cemaati içerisinde cereyan eden bir aşk hikâyesi bağlamında anlatır. (Enginün, 2016: 171). Yine bir eserin hangi edebiyata ait olduğu meselesini, eserin yazıldığı dil olarak 
gören bilim ve akademi dünyası için Vartan Paşa'nın eseri, Türk edebiyatında romanın tarihini yaklaşık yirmi yıl önceye götürmektedir. Zira Şemsettin Sami'nin Türkçe yazılan ilk roman olarak kabul edilen Taaşşuk-ı Talat ve Fıtnat'ının 1872-1873 y1llarında tefrika edildiği göz önünde bulundurulursa 1851'de yayımlanan Akabi Hikâyesi'nin önemi daha net anlaşılabilir. Benzer biçimde Türkiye'de roman türünün yerleşmesi konusunda önemli bir aşamayı temsil eden Evangelios Misailidis'in Grek harfleriyle Türkçe yazdığı dört ciltlik Temaşa-ı Dünya ve Cefekâr u Cefâkeş adlı hacimli eseri, Favini adlı bir avukatın doğumundan başlayarak ancak altmış beş yaşında sevgilisine kavuşmasına kadarki hayatını anlatır (Enginün, 2016: 172).

Türkiye'de minör edebiyata dair ibarelere, kanon içerisinde yer alan edebiyatçıların eserlerinde de rastlamak mümkündür. Nitekim Türk edebiyatında roman türünün yaygınlaşmasını sağlayan yazarların başında gelen Ahmet Midhat Efendi, farklı türlerde yazdığı kimi eserlerinde imparatorluğu oluşturan kavimlerin günlük yaşamına, kültürel ve tarihî birikimlerine dair önemli bilgiler verir. Hatta onun romanları tasnif edilirken "imparatorluğu oluşturan kavimlerle ilgili romanlar" (Enginün, 2016: 172) başlığı açılabilecek kadar epey bir yekûndan söz edilebilir. Örneğin Çingene, Karnaval, Gürcü Kızı, Arnavutlar Solyotlar, Kafkas gibi romanları Osmanlı Devletini oluşturan halklarla ilgili romanlardır ve Ahmet Midhat Efendi, bu romanlarında sosyal, kültürel ve politik göndermelerde bulunur. Elbette popüler bir romancı olması sebebiyle okur kitlesini genişletmeyi hedefleyen yazarın toplumsal yapıdaki renkliliği gözettiği söylenebilir. Neticede Osmanlıcılık fikrine bağlı olan Ahmet Midhat, "Osmanlı Devleti'ndeki çok ulusluluğa rağmen oluşan yekpareliğgi, bütünlüğü açıklar." (Enginün, 2016: 227). Öte yandan Ahmet Midhat Efendi'nin Çerkes Özdenler adlı oyunu da minör edebiyatın ilk nüvelerini barındıran bir metin olarak değerlendirilebilir. Zira "hem tiyatroda oynanmak hem de roman gibi okunmak üzere tertip olunan" (Enginün, 2016: 680) eseri, annesinin Çerkes olmas1 sebebiyle kaleme aldığını söyler. Eserin kapağında "milli dram" ibaresine yer verir ve oyunda, "Osmanlı İmparatorluğu'nun azınlıklarından olan Çerkezlerin yaşayış tarzlarını ve ahlâki inançlarını" (Akyüz, 1995: 63) anlatır. Hatta bu eser oynanırken tiyatronun kapatıldığ 1 ve İstanbul'da belirli bir süre tiyatro faaliyetlerinin askıya alındığı da göz önünde bulundurulursa oyunun dönemin yöneticileri tarafından sakıncalı görüldüğü söylenebilir.

Türk edebiyatının modernleşme süreci içerisinde, Minör bir söylemin izlerine rastlanabilecek edebiyatçılardan biri de Şemsettin Sami'dir. Şemsettin Sami, Türkçeyi incelemek, modernize etmek, sadeleştirerek geliştirmek ve öğretmek amaciyla önemli eserler meydana getirmesine rağmen kimi çevrelerce Arnavut milliyetçisi olarak suçlanmaktan kurtulamaz (Bilmez, 2005: 56). Bunun sebebi ise yazarın Arnavutça Alfabe (1879), Arnavutça Gramer (1886) ve Arnavutluk Ne idi, Nedir, Ne Olacak (1899) başlıklı çalışmalarının yanı sıra Arnavut geleneklerini Osmanlıca anlattı̆̆ı Besa yahut Ahde Vefa (1875) adlı piyesidir. Nitekim Şemsettin Sami, “bu eserinin ‘İfâde-i merâm' başlıklı ön sözünde mensubu olduğu Arnavut kavminin vatan sevgisi, birlik-beraberlik, yardımlaşma, fedakârlık ve ahde vefa gibi ahlâk, örf ve âdetlerine ait bazı özellikleri tasvir etmek üzere bir hikâye yazmayı öteden beri hayal ettiğini ancak daha sonra hikâyeye kıyasla daha etkili olacağı düşüncesiyle bunu tiyatro türünde verme kararını aldığını belirtmektedir." (Erol, 2016: 120). Güllü Agop'un Osmanlı Tiyatrosu'nda oynanan ve hemen ardından yasaklanan "altı fasıldan ibaret facia" diye tasvir edilen Besa yahud Ahde Vefa, "Arnavutların geleneksel yaşayışını ve kültürel unsurlarından törenin kutsadığı 'besa' yı, yani 'yemin'i öne çıkarır. Besâ, verilmiş söze bağllığın kanıtlanmaya çalışıldığı bir oyundur. Yazar, bu eserde genel olarak Arnavut halkının, özelde de olayların yaşandı̆̆ı Pargonatlı köylülerin ve Tepedelenli ile Burç bölgesindeki şehirlilerin yaşam tazını; örf, âdet ve töreyle olan ilişkilerini işlemektedir." (Erol, 2016: 120). Görüldüğü gibi Osmanlı edebiyatçılarının eserlerinde minör söylemin arkaik unsurlarına rastlamak mümkündür. Elbette bu tür metinleri modern anlamda minör edebiyat olarak değerlendirmek zordur. Fakat gerek Ermeni ve Grek alfabesiyle yazılan gerekse Osmanlıca üretilen birçok metinde farklı etnik, dini ve kültürel topluluğun yaşamına dair göndermeler vardır. $\mathrm{Bu}$ durum da Osmanlı imparatorluğunun çokkimlikli, çokkültürlü toplumsal dokusundan kaynaklanır. Çoğu zaman ülkenin 
politik ve sosyal dokusuna zarar vereceği endişesiyle baskılanan bu eğilim, yine de neşvünema bulacağı bir zemin bulur. Nihayetinde Osmanlı edebiyatı ve özellikle de Tanzimat'tan Cumhuriyet'e uzanan süreç boyunca üretilen edebiyat üzerine minör söylemin izlerini sürmek bağlamında yapılacak çalışmaların ortaya oldukça çarpıcı sonuçlar çıkaracağını eklemek gerekir.

Türkiye'de modern anlamda bir minör edebiyat ise ulus devlet dönemiyle yani Cumhuriyet'in kurulmasıyla ortaya çıkar. Ulus devlet paradigmasıyla kurulan Türkiye Cumhuriyeti ile birlikte kendi ana dilinde yazma imkânı bulamayan birçok edebiyatçı, Türkçe yazmaya yönelir. Böylece "minör bir söylem" Türk edebiyatında uç verir. Bu bağlamda dikkati çeken yazarların/şairlerin başında Türkçe yazan Kürt asıllı edebiyatçılar gelir. Elbette buradaki temel mesele etnik ve kültürel aidiyet meselesi değil; edebiyatçının eserlerine bu kimliğine ait unsurların "minör bir tarzda" sızmasıdır. Nitekim "ana dili olmayan bir dilde yazan yazar, o dilde yeni kullanım olanakları bulmak, dildeki sosyal hiyerarşileri alt üst edecek bir sarsılma sağlamak konusunda avantajlıdır; çünkü çemberin hem içinde hem dışındadır." (Erkol, 2010: 59). Bu nedenle Türkçe yazan Kürt şairler/yazarlar meselesinde ileri sürülen "iki dillilik bir kırılma yaratır, Türkçe yazmak demek Türk okur için yazmak demektir," tezine karş1 itidalli olmak; bunun yerine Türk edebiyatındaki "minör söylemi” edebiyatın, imgelemin, anlatım imkânlarının zenginleştirilmesi aracı olarak görmek daha doğrudur. Örneğin Türk edebiyatında en çok baskı yapan şiir kitaplarından birinin Ahmed Arif'in Hasretinden Prangalar Eskittim adlı şiir kitabı olması ve bu şiirlerdeki "minör söylemin" içerik ve biçim özellikleri açısından hangi imkânları taşıdığını tartışmak daha verimli olacaktır. Benzer biçimde Cemal Süreya şiirlerine rengini veren göç imgesi, tercih ettiği yayılgan imgelerin bireysel olandan çıkıp kolektif bilinçdışına yayılması ile mizahın, ironinin ve erotizmin alt zeminini oluşturan Ortadoğu coğrafyası ve politik söylem (Korkmaz, Özcan, 2011: 289) minör edebiyata dair önemli veriler içermektedir. Bu nedenle Cemal Süreya şiirini bir de minör edebiyat bağlamında değerlendirmek onun poetikasının bir başka yönünü açığa çıkarabilir.

Türkçe yazan Kürt yazarlar konusunda Mehmet Uzun ismi de sıkça telaffuz edilmektedir. Romanlarını Kürtçe; deneme, araştırma ve diğer türlerdeki eserlerini ise Türkçe ve İsveççe yazan Uzun, "Kafka gibi birden fazla dilin kesiştiği bir koordinatta bulunmaktadır." (Erkol, 2010: 59). Fakat çokdilli bir yazar olması Mehmet Uzun'u minör edebiyatçı yapmaz. Zira Mehmet Uzun, edebi üretimlerinin büyük çoğunluğunu Kürtçe kaleme alır. Türkçe ve İsveççe yazdığg eserlerinde ise Minör edebiyatın dil, anlatım ve üslûp özelliklerine pek yer vermez. Yine Türk edebiyatının önemli romancılarından Yaşar Kemal'in de dil, anlatım ve üslûp özellikleri ile minör edebiyat içerisinde değerlendirilmeyeceğini söylemek gerekir. Bu bağlamda minör edebiyatın izleri, hâlihazırda Türkçe yazan ve elbette minör edebiyatın içerik ve biçim özelliklerini kullanan yazarların/şairlerin eserlerinde aranmalıdır. Örneğin Suzan Samanc1, Murathan Mungan, Haydar Karataş, Kemal Varol, Yavuz Ekinci, Burhan Sönmez gibi yazarlar Türkçeyi yersizyurtsuzlaştırmaya çalıştıkları, dilin göçebesi olduklarını vurguladıkları, söylemleriyle alışılageldik kalıplara ve egemen söyleme karşı tavır aldıkları için minör edebiyatın alanındadırlar. Yine özellikle 1980 sonrası şiirinde yükselen bir eğilim olarak minör söylemin de özellikle Kürt kökenli şairler tarafından işlendiği söylenebilir. Hatta edebi görünürlüklerini 1990'lardan sonra kazanan ve 2000'li yıllardan sonra pekiştiren bu şairlerin çoğu Yaşar Nabi Nayır Gençlik Ödülü başta olmak üzere farklı platformlarda aldıkları ödüllerle varlıklarını duyururlar. Metin Kaygalak, Selim Temo, Bejan Matur, Mehmet Butakın, Azad Ziya Eren, Seyyidhan Kömürcü, Uğur Aktaş, Alper Gencer, Veysi Erdoğan, Mehmet Özkan Şüküran isimleri bu bağlamda öne çıkar. Bu şairler, "her yangından sonra 'suçu su'yun üstüne atmadan', şiirde de içkin olan mitik bir sabrı deneyerek şiirlerini yeniden başlatırlarken, sürüldükleri ve/veya göçtükleri dil'de de yeni bir başlangıcın müjdesini de verirler." (Sarığlu, 2004: 112). Bu minör söylem sayesinde Türk edebiyatı, kendi ötekileriyle yeniden tanışma imkânı bulabilir. Böylece kendi içerik ve üslûp imkânlarını da geliştirebilir. Neticede 1980 sonrası

- Ayrıntılı bilgi için bakınız. (Yasakmeyve, Ocak-Şubat 2004, S. 6., Dosya: Doğu'dan Zuhur Eden Şiirler; Türkçe Yazan Kürt Şairler) 
Türk şiirinin başlıca eğilimleri sayılırken araştırmacıların listeye dâhil etmediği "minör şiiir”, özellikle 2000 'li yıllar sonrası için yapılacak bir tasnifte önemli bir eğilim olarak değerlendirilmelidir. Son tahlilde edebiyat dünyasındaki görünürlüğü, aldıkları ödüllerle bir bakıma kendilerini edebiyat dünyasına kanıtlamaları ve okurdan gördükleri ilgi minör şiiri; Yeraltı şiiri, İslamî şiir, distopya şiiri, postmodern şiir ile birlikte 2000’li yıllar sonrasının başlıca şiir eğilimleri arasına sokar.

Türkiye'de minör edebiyatın bir diğer önemli damarını ise Ermeni, Rum, Yahudi kökenli yazarların üretimleri oluşturur. Bu bağlamda Sevim Burak, Bilge Karasu, Mario Levi, Roni Margulies gibi Yahudi asıllı yazarları/şairleri ya da Mıgırdiç Margosyan ve Markar Esayan gibi Ermeni yazarları (Erkol, 2010: 59) minör edebiyat bağlamında değerlendirebiliriz. "Bu yazarlar İbranice veya Ermenice değil Türkçe (majör dilde) yazdıklarında, Sevim Burak mırıltılarla örülü metinlerinde Tevrat göndermeleri yaptığında (Kafka'nın Yahudi teolojisine yaptığı göndermeleri hatırlayalım), Bilge Karasu deneysel metinlerle insanı kendine 'yabancı' yaban anlam labirentleri yarattı̆̆ında, Mario Levi İstanbul'dan gitmenin nostaljisini yıkıcı bir hüzne dönüştürdüğünde ya da Mıgırdiç Margosyan ve Markar Esayan dil/biçim oyunlarıyla metinlerinde geçmişe ve anılara uzandıklarında" (Erkol, 2010: 5960) göçebe-göçmen olma hâlini somutlaştırırlar.

Türkiye'de minör edebiyat gerek iç gerekse dış koşulların etkisiyle 2000'li yıllardan sonra görünürlük kazanır. Küreselleşme, göçler, ulaşım ve haberleşme teknolojisinin evirildiği boyut, çokkültürülü, çokkimlikli toplumsal atmosferin oluşumu, geleneksel, tarihî, etnik ve kültürel köklere dönme çabası çağın kültürel mantığı olan postmodernizmle birleşince minör bir söylemin gelişmesi kaçınılmaz olur. Bir taraftan edebiyatçılar eserlerinde bu çokdilli, eklektik, melez, karnavalesk ortamdan beslenir; öte taraftan ise araştırmacılar, akademisyenler, edebiyat tarihçileri; tüm edebiyat ve sanat tarihini minör edebiyatın perspektifinden yeniden değerlendirme çabasına girişirler. Tüm bu gelişmelere rağmen Türkiye'de minör edebiyat üzerine yapılan çalışmalar oldukça sınırlıdır. Yapılan çalışmalar ve araştırmalar ise çoğu zaman bütünlüklü bir çalışmadan ziyade tek bir edebiyatçı ya da eser üzerinden yürütülür. Örneğin Herkül Milas'ın Türk Romanı ve 'Öteki' adlı kitabı Türk romanında ötekilerin, azınlıkların nasıl ele alındığı meselesini irdelerken genel anlamda "Türk ulusal kimliğinin inşasında Yunan imajı" temasına odaklanır. Sabancı Üniversitesi'nden Alparslan Nas ise Türkiye'de Milli ve Minör Edebiyat Arasinda: Mehmed Uzun ve Migirdiç Margosyan'ın Eserlerinde Direniş Modelleri adlı yüksek lisans tezinde Ermeni yazar Margosyan ve Kürt yazar Mehmed Uzun'un eserlerinden hareketle iki yazardaki minör söylemi karşılaştırmalı olarak irdeler. Yine Bilgi Üniversitesi'nden Angeliki Melliou, Psikanalitik Yaklaşımla Çağdaş Türk Edebiyatı ve Çağdaş Yunan Edebiyatı Karşılatırması: Sevim Burak ve Margarita Karapanoun'un Çalı̧̧malarında Anne - Kız İlişkisi ve Anne Figürü adlı yüksek lisans tezinde Burak ve Karapanoun'un eserlerinde kimlik meselelerini karşılaştırmalı ve psikolojik bir yaklaşımla ele alır. Van Yüzüncü Yıl Üniversitesi'nden Harun Arvas ise Sevim Burak Eserlerinde Minör Edebiyatın İzleri adlı yüksek lisans tezinde, Deleuze ve Guattari'nin kavramsal çerçevesini çizdiği minör edebiyatın Burak'ın eserlerine yansımalarını irdeler. Bu tür kitap ve tezlerin yanı sıra makale, bildiri ve kimi edebiyat dergilerinin hazırladıkları minör edebiyat konulu dosyalara da rastlamak mümkündür.

\section{Sonuç}

Modernizmin yaşadığı kriz, büyük ideolojik anlatılara olan güvenin sarsılması, mikro milliyetçilikler, azınlık araştırmaları, göçler, öteki kimliklerin kendini ifade edebileceği sosyal platformların çoğalması; minör edebiyat söylemini yaygınlaştırmıştır. Nitekim içinde yaşadığımız küreselleşme çağında; haberleşme, internet teknolojisi, sanal ağlar, ulaşım imkânları, göçler, savaşlar, turizm vb. etkinlikler dünyayı global bir platform hâline getirmiştir. Dolayısıyla minör bir edebiyat da dünyanın birçok ülkesinde görülen, bilinçli ya da bilinçsiz bir biçimde üretilen bir edebiyat sahasına dönüşmüştür. Çokdillilik, çokkültürlülük, dini ve etnik bakımdan melezlik, postkolanyal atmosferin ortaya çıkardığı majör dili azınlıklar lehine yeniden üretmek gibi durumlar, içinde yaşadığımız çağın 
edebiyat dünyasını algılamak konusunda minör edebiyattan yararlanmayı zorunlu kılmaktadır. Nitekim Deleuze ve Guattari'nin haklı olarak sorduğu; "dünyada şu an Anglosakson bir hegemonyanın hâkimiyeti altında kendilerinin olmayan bir dilde yaşayan ne kadar insan vardır? Kendi dilini dâhi bilmeyen kaç insan vardır? Hatta kendi ana dilini ne kadar biliyor ve yahut kullanmaya zorlandıkları majör dili bile iyi bilmeyen kaç insan vardır?" gibi sorular çoğaltılabilir. Örneğin artık, iki ya da üç kuşaktır başka bir ülkede yaşayan göçmenlerin ürettiği edebiyat hangi kültürel, etnik, sosyolojik ve psikolojik durumların tezahürüdür? Ulusal edebiyatların sonu mu gelmektedir? Bundan böyle herkes kapsamlı ve genel bir Dünya edebiyatı şemsiyesi altında kendi minör edebiyatını mı üretecektir? Yoksa mikro milliyetçilikler çağında her etnik, kültürel, dinî grup, ana akımdan koparak yerel edebiyatına mı yelken açacaktır? Özel hayatın kamusal alana taşındığı bu gösteri toplumunda bundan böyle azınlıklar, majör dildeki anlatım imkânlarını zorlamak yerine; herhangi bir sansürlemeye başvurmadan kendi dillerinde mi edebiyat yapacaktır? Belki de minör bir yazar, majör dilde kolektif söylemini ve politik duruşunu dili yersizyurtsuzlaşmaya vardırmadan olduğu gibi açıkça ifade edecektir. Böylece ta başında Deleuze ve Guattari'nin saptadığı üç özellik ikiye düşecek, minör edebiyat, azınlığın kolektif bir söylemine odaklanan, açık, doğrudan ve aleni mesajlar veren politik bir edebiyat türüne dönüşecektir. Neticede "minör bir edebiyatın kendi dilinden nasıl kopup, egemen dile meydan okuyan, bilinçli bir itiraz söylemi geliştirmesi nasıl oluşur? $\mathrm{Bu}$ söylem egemen dilde hangi gedikleri açarak ve dili eşeleyerek kurulur?" gibi sorular da tedavülden kalkacaktır. Ama öte yandan tüm bu sorunların ortadan kalkması minör edebiyatın alanını daraltmayacak feminizmle başlayıp ekoloji, Yeraltı edebiyatı, distopya, marjinal yaşamlar, eşcinsellik, alt kültür akımları, distopya ve e-edebiyat gibi yeni sayılabilecek türlerin katılımıyla başka bir boyuta evirilecektir. Neticede Kafka'nın metaforik ifadesiyle "beşikte çaldığı bebekle ipte yürümek" işi bu sefer; feminist, çevreci, Yeraltı veya distopya yazarlarının omuzlarında yükselecektir.

\section{KAYNAKÇA}

Adar, E. (2016). "I forgot half the words": Samuel Beckett's Molloy as Minor Literature, Johns Hopkins University Press (Charles University, Prague), Journal of Literature and the History of Ideas, Volume 14/1, s. 21-31.

Akyüz, K. (1995). Modern Türk Edebiyatının Ana Çizgileri 1860-1923, İstanbul: İnlıkâp Kitapevi.

Barber Stetson, C. (2014). Slow Processing: A New Minor Literature by Autists and Modernists, Published by Indiana University Press (University of Illinois at Urbana-Champaign), Journal of Modern Literature, Volume 38/1, s. 47-165.

Batu, P., Kaygalak, M. (E.T. 12.06.2018). Koyu Edebiyat (Televizyon Program1), www.youtube.com.

Bayrak, Ö. (ed.) (2016). Sorularla Yeni Türk Edebiyatı, İstanbul: Kesit Yayınları.

Bensmaila, R., Deleuze G. Ve Guattari, F. (2017). Kafka Efekt/Minör Edebiyat nedir?, İstanbul: Sub Yayınc1lk.

Bilmez, B. (2005). "Şemseddin Sami mi Yazdı Bu Sakıncalı Kitabı?", Tarih ve Toplum, s. 97-145.

Deleuze, G. (2007). Kritik ve Klinik, İstanbul: Norgunk Yayınları.

Deleuze, G., Parnet, C. (1990). Diyaloglar, İstanbul: Bağlam Yayınları.

Deleuze, G., Guattari, F. (2015). Kafka: Minör Bir Edebiyat İçin, İstanbul: Dedalus Yayınları.

Demirtaş, M. (2015). Postyapısalcı Edebiyat Kuramı/Sevim Burak, Edebiyatta Bir Tekillik Düşünürü, İstanbul: Otonom Yayıncilik. 
Enginün, İ. (2016). Yeni Türk Edebiyatı Tanzimat'tan Cumhuriyet'e (1839-1923), İstanbul: Dergâh Yayınları.

Erkol, G. Ç. (2010). “Türkiye’de 'Göçebe’ Olmak ve Edebiyat Yapmak”, Lacivert Öykü ve Şiir Dergisi, S.33, s. 56-60.

Erol, K. (2016). “Şemsettin Sami’nin Besa ve Gâve Alı Piyeslerinde Sömürüye Karşı Politik Eleştiri”, Uluslararası Sosyal Araştırmalar Dergisi, Volume 9/44, s. 117-128.

Fletcher, J. (2011). “... ha perdut la veu: Some reflections on the compositions of e - literature as a minor literature, University College Falmouth, Volume 4/1, s. 53-63.

Gale, K. (2016). "Writing Minor Literature: Working with Flows, Intensities and the Welcome of the Unknown", Plymouth University, Volume 22/5, s. 301-308.

Gilmore, C. (2015). "A Minor Literature in a Major Voice: Narrating Nubian Identity in Contemporary Egypt", American University in Cairo Press, s. 52-74.

Güçbilmez, B. (2003). “Tekinsiz Tiyatro: Sahibinin Sesi/Sevim Burak'ın Metninde Tekinsiz Teatrallik ve Minör Sesin Temsili”, Tiyatro Araştırmaları Dergisi, S.16, s. 1-17.

Güçbilmez, B. (2017). "Yazının Kalbine Yürüyen İğne”, Notos Öykü, S. 65, s. 38 - 41.

Korkmaz, R., Özcan, T. (2011). Yeni Türk Edebiyatı El Kitabı (ed. Ramazan Korkmaz), Ankara: Grafiker Yayınları.

Kuyumcu, M. (2010). “Özgür Balık Akvaryuma Karş1”, Lacivert Öykü ve Şiir Dergisi, S.33, s. 69-70.

Murray, T. (1997). The Politics of Theatricality in Contemporary French Thought, Gilles Deleuze, "One Less Manifesto", USA:The University of Michigan Press.

Özçınar, M. (2017). "Deleuzyen Sinema: Minör Bir Oluş Olarak Sarmaşık Filminin Rizomatik Yapısı", SineFilozofi Dergisi, Volume 2/4, s. 73-93.

Pazarkaya, Y. (2018). “İkinci Dilde Yazmak”, Kitap-lık Dergisi, S. 199, s. 126-129.

Sarıŏlu, S. (2004). "Eşik’te ve Öte-bölge'de Yazılan Şiirler”, Yasakmeyve Dergisi, S. 6, s. 112-119.

Sutton, D., Jones, D. M. (2016). Yeni Bir Bakışla Deleuze, İstanbul: Kolektif Kitap.

Şahin, Ö. (2015). Ötekilere Yazmak Sevim Burak Üzerine Yazılar, İstanbul: Yapı Kredi Yayınları.

Şahin, S. (2017). “Ölüm Saatleri’nde Birleşen Anlatıcı ve Kahraman”, Notos Öykü, S. 65, s. 42-46. Taş, M. R. (2018). Sömürgecilik Sonrası İngiliz Romanında Eğitim, İstanbul: Cinius Yayınları.

Tuncay, O. (2012). Kafka yı Kullanma Kılavuzu - Bir Fenomen Olarak Kafka, İstanbul: Nokta Kitap. 